\title{
Complex effects of chytrid parasites on the growth of the cyanobacterium Planktothrix rubescens across interacting temperature and light gradients
}

\author{
Joren Wierenga ${ }^{1}$, Mridul K. Thomas ${ }^{1}$, Ravi Ranjan ${ }^{2,3}$, Bas W. Ibelings ${ }^{1}$ \\ ${ }^{1}$ Department F.A. Forel for Environmental and Aquatic Sciences and Institute for Environmental Sciences, University of \\ Geneva, Geneva, Switzerland \\ ${ }^{2}$ Helmholtz Institute of Functional Marine Biodiversity at the University of Oldenburg (HIFMB), Ammerländer Heerstraße \\ 231, D-26129 Oldenburg, Germany \\ ${ }_{3}^{3}$ Alfred-Wegener-Institute, Helmholtz-Centre for Polar and Marine Research (AWI), Am Handelshafen 12, 27570 \\ Bremerhaven, Germany
}

\begin{abstract}
Chytrids are important drivers of aquatic ecosystems as phytoplankton parasites. The interaction between these parasites and their hosts are shaped by abiotic factors such as temperature and light. Here, we performed a full-factorial experiment to study how temperature and light interact to affect the dynamics of the bloom-forming toxic cyanobacterium Planktothrix rubescens and its chytrid parasite. We used a dynamic hostparasite model to explore how temperature and light affect long term dynamics. At low temperatures, chytrids do not survive. Higher light and temperature levels stimulated both phytoplankton and chytrid growth, with complex effects on their dynamics. Model exploration indicates that increasing temperature and light shifts equilibrium outcomes from $P$. rubescens persisting alone to stable coexistence and then to limit cycles. This provides an alternative biological explanation for why $P$. rubescens is mainly found in the relatively cold and dark lake metalimnion - it may enable avoidance of its parasite. Our study emphasizes the importance of investigating how abiotic factors interact with biotic interactions to drive complex outcomes.
\end{abstract}

\section{Introduction}

Cyanobacteria are important primary producers in aquatic systems (Díez \& Ininbergs, 2013), but are considered harmful when they form dense blooms often containing high concentrations of toxins (Fristachi et al., 2008; Huisman et al., 2018; Plaas \& Paerl, 2021). Planktothrix rubescens is a common species of cyanobacteria that often produces toxic blooms, with high concentrations of hepatotoxins like microcystins or neurotoxins like anatoxin-a (Kurmayer et al., 2016; Rohrlack et al., 2013). It is typically found in the metalimnion of deep stratifying lakes, and is adapted to lower light and temperature conditions than other cyanobacteria (Legnani et al., 2005; Walsby et al., 2004). (Bruning, 1991a; Rohrlack et al., 2015; Tao et al., 2020). P. rubescens has a very efficient light harvesting complex composed of both phycocyanin and phycoerythrin in addition to chlorophyll, which allows it to continue photosynthesis at light levels below that of many other phytoplankton species (Davis \& Walsby, 2002; Oberhaus et al., 2007). In stratified lakes $P$. rubescens is often found at the depth where the irradiance is $0.1 \%-1 \%$ of that at the 
surface $\left(\approx 1-20 \mu \mathrm{E} \mathrm{m}^{-2} \mathrm{~s}^{-1}\right)$. They maintain themselves in this position due to light-mediated buoyancy regulation, consisting of lift provided by gas vesicles offset by carbohydrate ballast (Walsby, 2005). Even though $P$. rubescens can grow at low light and temperature, its growth rate increases with temperature and light, including at values well outside the narrow range they typically experience in their natural habitats (Bright \& Walsby, 2000; Oberhaus et al., 2007; Walsby, 2005). Why P. rubescens is rarely seen in high-light, high-temperature conditions that would appear to favour its growth remains an open question.

The dynamics of cyanobacteria are driven by abiotic factors such as temperature, nutrients, and light (Conroy et al., 2017; Sommer et al., 1986, 2012). Generally speaking, growth increases with increased light and increased temperature, but only up to optimal values (Reynolds, 2009) that vary between species and strains. The responses to light and temperature are skewed unimodal functions; both high temperature and high light levels lead to cell damage and ultimately death (Han et al., 2000). Temperature and light interact to exacerbate these negative effects (Edwards et al., 2016; Ibelings, 1996). Understanding how the environment shapes the dynamics of $P$. rubescens (or any phytoplankton species) therefore requires us to examine how these abiotic factors interact to shape its growth and biotic interactions. The size and complexity of such experiments means that they are rarely performed, weakening our ability to understand how environmental change affects natural populations and communities.

Parasites are important biotic drivers of ecological communities, commonly affecting cyanobacteria as well as other species of phytoplankton (Hatcher \& Dunn, 2011; Marcogliese, 2004; Sime-Ngando et al., 2007). Even though parasitism is one of the most common consumer strategies on earth, herbivorous grazers have been the focus of interest as biotic drivers of phytoplankton community dynamics (Sommer et al., 1986, 2012), and parasites remain understudied (Frenken et al., 2017). Parasites have been shown to impact host populations of primary producers, with knock-on-effects at higher trophic levels and may change the whole community structure (Brussaard et al., 2005; Gerphagnon et al., 2009; Gleason et al., 2015; Ibelings et al., 2011; Kagami, De Bruin, et al., 2007). One of the most ubiquitous group of parasites in aquatic ecosystems belong to the Chytridiomycota, a large and diverse group of fungi that are known to infect many species of algae and cyanobacteria, including $P$. rubescens. Chytrids are most known for the role they play in amphibian extinctions worldwide (Lips et al., 2005; McKenzie \& Peterson, 2012; Skerratt et al., 2007). They have been shown to be involved in the termination of blooms of cyanobacteria and other phytoplankton species (Bosch et al., 2001; Bruning et al., 1992; Paterson, 1960; Șen, 1988; van Donk \& Ringelberg, 1983). Chytrid infection can furthermore act as a shunt in aquatic ecosystems, transferring nutrients and carbon carried in their zoospores to higher trophic levels through infection of phytoplankton that are otherwise resistant to grazing (Agha et al., 2016; Frenken et al., 2018; Kagami, von Elert, et al., 2007).

The chytrid parasite is also affected by temperature and light, both through the direct effects of temperature on its physiological processes, and through temperature and light effects on the host (Bruning, 1991a; Rohrlack et al., 2015; Tao et al., 2020). However, we do not know how light and temperature interact to affect chytrid infection of $P$. rubescens. Light affects the release of dissolved organic carbon (DOC) by phytoplankton (Fallowfield \& Daft, 1988; Mueller et al., 2016), which subsequently impacts chemotaxis of chytrid zoospores, and thus infection 
dynamics (Bruning, 1991c, 1991a; Tao et al., 2020; Van den Wyngaert et al., 2013). Much of the work on chytrid - host interactions has been done on the diatom Asterionella formosa and an associated chytrids, Rhizophydium planktonicum and Zygorhizidium planktonicum. In these host-parasite pairs, both low temperature and low light can (independently) provide refuge for the host, in which the chytrid infection is not sustained (Bruning, 1991a, 1991c). For $P$. rubescens, low temperatures alone have also been shown to offer refuge against chytrid infections (Rohrlack et al., 2015). The term 'refuge' in this case does not indicate a physical location but instead a set of environmental conditions that prevents chytrid infection. A recent study has shown that increasing the quantity and quality of light increases chytrid infection of $P$. rubescens (Tao et al., 2020). Because of the vertical position of $P$. rubescens in the lake, it is typically subjected to relatively large variations in temperature and light across the steep environmental gradients in its metalimnetic population.

Here we investigated how light and temperature interact to shape Planktothrix-chytrid interactions using a combination of experiments and theory. We performed a full-factorial experiment that features four temperatures, four light levels and two infection statuses (infected and uninfected $P$. rubescens cultures). We extended a dynamic host - parasite model (Almocera et al., 2019; Frenken et al., 2020; Gerla et al., 2013; Miki et al., 2011) to explore the consequences of temperature-light interactions for $P$. rubescens - chytrid dynamics. To examine this specific system, we made model parameters dependent on temperature and light and estimated them from our experiment where possible. We investigated whether the thermal refugium for $P$. rubescens depends on light intensity, indicating that abiotic interactions co-shape these ecologically important biotic interactions. We demonstrate that increasing light and temperature stimulated both phytoplankton and chytrid growth, with complex effects on host-parasite interactions.

\section{Materials and Methods}

\section{Experimental design}

We used a full factorial experimental design with 4 temperatures $\left(6,11,16\right.$ and $\left.21{ }^{\circ} \mathrm{C}\right), 4$ light levels (2, 7, 14 and $\left.21 \mu \mathrm{E} \mathrm{m}^{-2} \mathrm{~s}^{-1}\right)$ and 2 infection status levels (infected/uninfected P. rubescens cultures), for a total of 32 treatment combinations. We used 4 replicates at each combination, for a total of 128 experimental units.

\section{Culture details and experimental conditions}

Planktothrix rubescens strain NIVA-CYA98 and the chytrid parasite Chy-Kol20o8 that were used in this study are monoclonal but non-axenic; bacterial biomass was kept low by semi continuous growth, confirmed by microscopy. Before the onset of the experiment the $P$. rubescens cultures were acclimated to the different experimental conditions. WC-medium was used to grow P. rubescens (Guillard \& J.Lorenzen, 1972), modified to exclude silicon as a macronutrient. Temperature was regulated by using heated water baths in a refrigerated room at $4{ }^{\circ} \mathrm{C}$, logged with calibrated temperature loggers (HOBO Onset, UX120-oo6M). Light was provided by fluorescent tubes (cool-white), and light intensities were manipulated using neutral density filters shading the culture flasks (manufactured by Lee Filters, Hampshire UK, 
filters numbers 211, 210 and 209). Photoperiod was set to a 16:8 hour cycle of light and dark. The experiment was performed in $250 \mathrm{~mL}$ culture flasks (Greiner Bio One, Item No.: 658195).

At the start of the experiment the culture flasks were filled with $100 \mathrm{~mL}$ of $P$. rubescens suspension, diluted to a biovolume of $4 \mathrm{~nL} \mathrm{~mL}^{-1}$, so all treatments had the same density at the start of the experiment. Subsequently, half of these flasks were put in the infected treatment and thus were inoculated with a dense zoospore suspension. The suspension was made by filtering a heavily infected culture of $P$. rubescens through a glass serological pipet filled with loosely packed glass fibers that had been autoclaved. The glass fiber filter that is created this way lets through most of the zoospores but is highly efficient in removing the filaments of $P$. rubescens. One $\mathrm{mL}$ of this dense zoospore suspension was added to the infected treatment, resulting in 70 zoospores $\mathrm{mL}^{-1}$ at the start of the experiment. The experiment lasted for 20 days.

\section{Sampling and imaging}

$2 \mathrm{~mL}$ samples were taken every other day during the course of the experiment and fixed in $0.5 \%$ final concentration glutaraldehyde. The samples were stored in $2 \mathrm{~mL}$ sample tubes at 4 ${ }^{\circ} \mathrm{C}$.

To analyze the samples from 128 experimental units, a high throughput biovolume measurement method was developed (Wierenga et al., in prep). The method relies on high resolution composite images of the entire surface of a clear bottom well, imaged by an automated microscope. $300 \mu \mathrm{L}$ of each sample was pipetted in duplicate into a clear bottom 96-well plate (Greiner Bio one Item No: 655096) for image analysis. The plates were put in the fridge for 24 hours, to allow enough time for settling of the filaments. Using a Biotek cytation3, image composites were taken of the entire surface of each well bottom with a $4 \mathrm{x}$ magnification objective. Images were taken in the chlorophyll and phycoerythrin autofluorescence channel ( $586 \mathrm{~nm}$ excitation and $647 \mathrm{~nm}$ emission). This yields high quality images with bright filaments against a dark background, ideal for image analysis. For infection measurements $300 \mu \mathrm{L}$ fixed sample was pipetted in duplicate into clear-bottom 96-well plates. The plates were put in the fridge for 24 hours, to allow enough time for settling of the filaments. To visualize the chytrid sporangia, $10 \mu \mathrm{L}$ calcofluor-white (CFW) was added to each well to get a $5 \mu \mathrm{g} / \mathrm{mL}$ final solution. To increase fluorescence output of the CFW stain, $10 \mu \mathrm{L}$ of sodium hydroxide $(\mathrm{pH}>13.5)$ was added to increase the $\mathrm{pH}$ in the well. After incubation for 10 minutes, the plates were imaged with the Biotek cytation-3, in three different channels: brightfield, chlorophyll and phycoerythrin autofluorescence ( $586 \mathrm{~nm}$ excitation, $647 \mathrm{~nm}$ emission), and CFW ( $377 \mathrm{~nm}$ excitation, $447 \mathrm{~nm}$ emission). These composite images were combined to generate images which clearly show the outline of the filaments and stained sporangia. Furthermore, the viability of filaments can be assessed from the autofluorescence signal in the images.

\section{Image analysis}

To measure the biovolume, the autofluorescence image composites were analyzed with the open-source image analysis tool ImageJ, using the plugin skeletonize. In short, this method uses a "Skeletonization algorithm" to compute the total length of all filaments in a picture. These are subsequently converted to biovolume using the equation for calculating the volume of a cylinder $\left(V=\pi \cdot r^{2} \cdot l\right.$ ), where $r$ is the mean radius of filaments and $l$ is the total length of 
all filaments. The method is robust and can handle relatively high concentrations in samples because overlapping filaments is not a big problem. It requires only limited human input, reducing bias. Furthermore, with this method a relatively big sample of $300 \mu \mathrm{L}$ is measured in its entirety, compared to manual counting of only a fraction of that volume, thereby improving precision.

To measure infections during the experiment, in the composite infection images a minimum of 50 filaments were measured and marked as infected or uninfected. Instead of using the frequency of infected and uninfected filaments to calculate the prevalence of infection, we used the length of infected and uninfected filaments. This results in a better representation of the prevalence of infection because there is a large variation in length, and moreover, infected filaments are typically shorter than uninfected filaments.

\section{Data analysis}

Data analysis and graphing was done using R, version 4.0.4 and RStudio. (R Core Team, 2021; RStudio Team, 2021). ggplot2 (version 3.3.5) was used to make the graphs and the data processing was done with the help of the tidyverse packages (version 1.3.1) (R Core Team, 2021; RStudio Team, 2021; Wickham, 2016; Wickham et al., 2019). Comparisons of means were done using the robust yuen t-test from the package PairedData version 1.1.1 (Champely, 2018)

\section{Dynamical model}

We used a dynamical host - parasite model to assess the dependence of chytrid phytoplankton dynamics on temperature and light. We modified a model from (Frenken et al., 2020) by incorporating temperature- and light-dependence of the parameters. The model consists of three equations, which track the dynamics of uninfected hosts $\left(H_{u}\right)$, infected hosts $\left(H_{i}\right)$ and free-swimming zoospores $(Z)$.

The uninfected host $H_{u}$ follows logistic growth with a carrying capacity $K\left(\mathrm{~nL} \mathrm{ml} l^{-1}\right)$ and a growth rate $r\left(\right.$ day $\left.^{-1}\right)$. Losses of uninfected host are defined by a density-independent mortality rate: $m_{u}\left(\right.$ day $\left.^{-1}\right)$, and by infection of uninfected host by a zoospore, which converts uninfected host into infected host. The infectivity constant $I\left(\mathrm{~mL} \mathrm{cell}^{-1}\right)$ is a measure for the infection efficiency of zoospores $\left(\mathrm{mL}\right.$ cell $\left.^{-1}\right)$.

$$
\frac{d H_{u}}{d t}=r H_{u}\left(1-\frac{H_{u}}{K}\right)-m_{u} H_{u}-I H_{u} Z
$$

Infected hosts $H_{i}$ increase with every uninfected host that gets infected by the attachment of a zoospore. This is the same element as the loss due to infection for the uninfected host $\left(I H_{u} Z\right)$. Infected host decreases with a density-independent mortality rate $m_{i}\left(\right.$ day $\left.{ }^{-1}\right)$ and with maturation of sporangia given by the development time $\tau$ (days). The maturation of sporangia assumes infected host $H_{i}$ is converted into zoospores.

$$
\frac{d H_{i}}{d t}=I H_{u} Z-\left(\frac{1}{\tau}\right) H_{i}-m_{i} H_{i}
$$

201 Chytrid zoospores $Z$ increase when sporangia develop with development time $\tau$ and release new zoospores. The zoospore production parameter $\rho$ (cells $\mathrm{nL}^{-1}$ ) defines the number of spores produced per biovolume of infected host. Spores are lost when they infect an uninfected host, and additionally at a density-independent mortality rate $m_{z}\left(\right.$ day $\left.^{-1}\right)$. 


$$
\frac{d Z}{d t}=\left(\frac{p}{\tau}\right) H_{i}-I H_{u} Z-m_{z} Z
$$

205

Model parameter values: Some model parameters (Table 1 ) were calculated directly from our experimental data: the infectivity parameter $I$ and the growth rate $r$, making them functions of light and temperature. The infectivity parameter $I$ is calculated by assuming exponential decay of $H_{u}$ with $Z$, and is directly calculated from experimental data according to the following equation:

$$
I=-\frac{\ln \left[\frac{H_{u}(t)}{H_{u}\left(t_{0}\right)}\right]}{Z\left(t_{0}\right) t}
$$

where $t_{0}$ is the beginning of the experiment and $t$ is the length of the chosen period over which $I$ was calculated ( 2 days, see supplementary information for details). The phytoplankton growth rate $r$ was determined by fitting an exponential model to $P$. rubescens density over time in the uninfected treatments. To run the dynamical model at a higher resolution for temperature and light than the intervals used for the experiment, a generalized additive model (GAM) was fitted to calculated values of $r$ and $I$ across the temperature and light levels used in the experiment. This GAM-model was subsequently used in the dynamical host - parasite model to generate values for $r$ and $I$ at interpolated temperature and light. The parameters $K$ and $\rho$ are kept constant. The carrying capacity is set at $600\left(\mathrm{~nL} \mathrm{~mL}^{-1}\right)$, based on a logistic fit through experimental data at high light and temperature. The production of zoospores is $\rho$ calculated from supplementary data from (Frenken et al., 2020), which has zoospore production data on a very closely related strain of P. rubescens and chytrids (Frenken et al., 2020). It is calculated by dividing newly produced zoospores by the biovolume of the host 2 days prior, and is found to be 20 cells $\mathrm{nL}^{-1}$, which is set for each temperature and light combination. Infective lifetime of zoospores was found to be 2.71 days at $17^{\circ} \mathrm{C}$. This translates into a mortality rate $m_{z}$ of 0.37 (day ${ }^{-1}$ ) which we set to exponentially increase with temperature. Development time for sporangia is found to be between 2 and 3 days based on routine observations of infected cultures and is set to exponentially decrease with temperature. The dynamical model was analyzed in $\mathrm{R}$ using the R Package: deSolve, version 1.28 (Soetaert et al., 2010). 
231 There is no straightforward way to calculate the mortality rates $m_{u}$ and $m_{i}$ from available data;

232 we therefore assumed $m_{u}$ to be equal to $1 \%$ of the maximum growth rate at each temperature

233 (i.e. growth rate at the highest light level, $21 \mu \mathrm{E} \mathrm{m}^{-1} \mathrm{~s}^{-1}$ ). The mortality rate of infected

$234 \quad P$. rubescens is based on the same fit, with a 50 percent higher dependency on temperature

235 and a higher initial value to account for the increased mortality due to infection. For more

236 details about this temperature and light dependence, please refer to the supplementary

237 information.

Table 1: Overview of all parameters and variables used in the dynamical model. Where possible parameters were based on data from our experiment or from previous experiments with closely related organisms. The dependence of the parameters on either temperature, light or both is indicated.

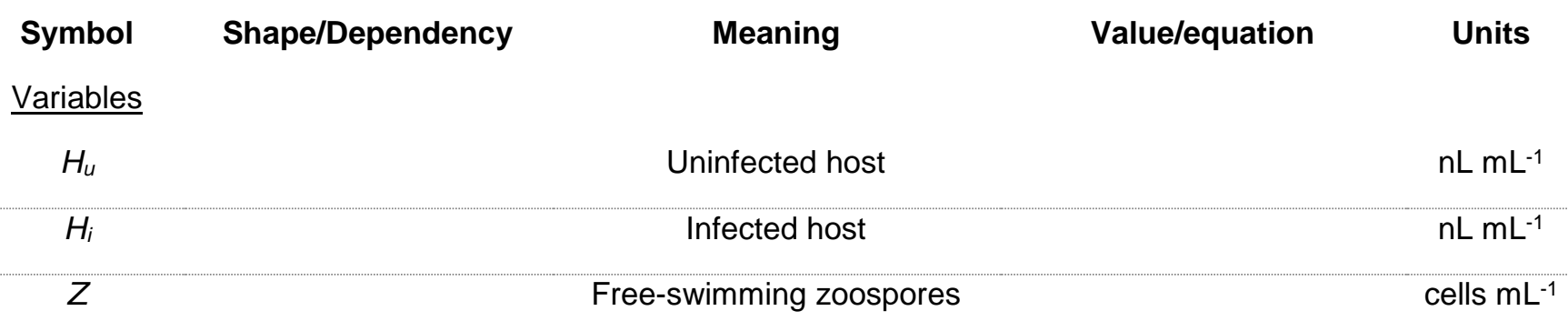

\section{$\underline{\text { Parameters }}$}

\begin{tabular}{|c|c|c|c|c|}
\hline$K$ & Constant & Carrying capacity & 600 & $\mathrm{~nL} \mathrm{~mL}^{-1}$ \\
\hline$I$ & $\begin{array}{c}\text { GAM with temperature } \\
\text { and light }\end{array}$ & Infectivity & GAM model & $\begin{array}{l}\mathrm{mL} \text { cell }^{-1} \\
\text { day }^{-1}\end{array}$ \\
\hline$r$ & $\begin{array}{c}\text { GAM with temperature } \\
\text { and light }\end{array}$ & $\begin{array}{c}\text { Growth rate of the uninfected } \\
\text { host }\end{array}$ & GAM model & day $^{-1}$ \\
\hline$m_{u}$ & $\begin{array}{l}\text { Exponential increase } \\
\text { with temperature }\end{array}$ & Death rate of uninfected host & $m_{u}=4.62 \cdot 10^{-4} \cdot e^{0.0783 \cdot T}$ & day $^{-1}$ \\
\hline$m_{I}$ & $\begin{array}{l}\text { Exponential increase } \\
\text { with temperature }\end{array}$ & Death rate of infected host & $m_{i}=0.0305 \cdot e^{0.117 \cdot T}$ & day $^{-1}$ \\
\hline$p$ & Constant & $\begin{array}{l}\text { Zoospore production per } \\
\text { biovolume of infected host }\end{array}$ & 20 & cells $\mathrm{nL}^{-1}$ \\
\hline$m_{z}$ & $\begin{array}{l}\text { Exponential increase } \\
\text { with temperature }\end{array}$ & Death rate zoospores & $m_{z}=0.035 \cdot e^{0.128 \cdot T}$ & day $^{-1}$ \\
\hline$\tau$ & $\begin{array}{l}\text { Exponential decrease } \\
\text { with temperature }\end{array}$ & $\begin{array}{l}\text { Development time of } \\
\text { zoospores in sporangia }\end{array}$ & $\tau=16.42 \cdot e^{-0.099 \cdot T}$ & $\begin{array}{l}\text { Time in } \\
\text { days }\end{array}$ \\
\hline
\end{tabular}




\section{Results}

Temperature and light effects on uninfected and infected Planktothrix growth rates Temperature and light interacted to shape the growth of $P$. rubescens and its susceptibility to chytrid infections (Fig. 1, Tables 1, 2). The expected cold refuge (Rohrlack et al., 2015) occurred in our experiments at temperatures of $11{ }^{\circ} \mathrm{C}$ and lower; no infections occurred at $11{ }^{\circ} \mathrm{C}$ and below. The growth rate of $P$. rubescens generally increased with both temperature and light at the levels tested in this experiment, but the shape of the interaction was complex. At low temperature, increasing light had no effect on growth. At low light, increasing temperature above $11{ }^{\circ} \mathrm{C}$ decreased growth rate (Fig. 1). Furthermore, the positive effect of temperature on the growth rate increased with light, whereas the positive effect of light on the growth rate, increased only till $14 \mu \mathrm{E} \mathrm{m}^{-2} \mathrm{~s}^{-1}$, after which growth rate did not change (Fig. 1D, lines on top of each other).
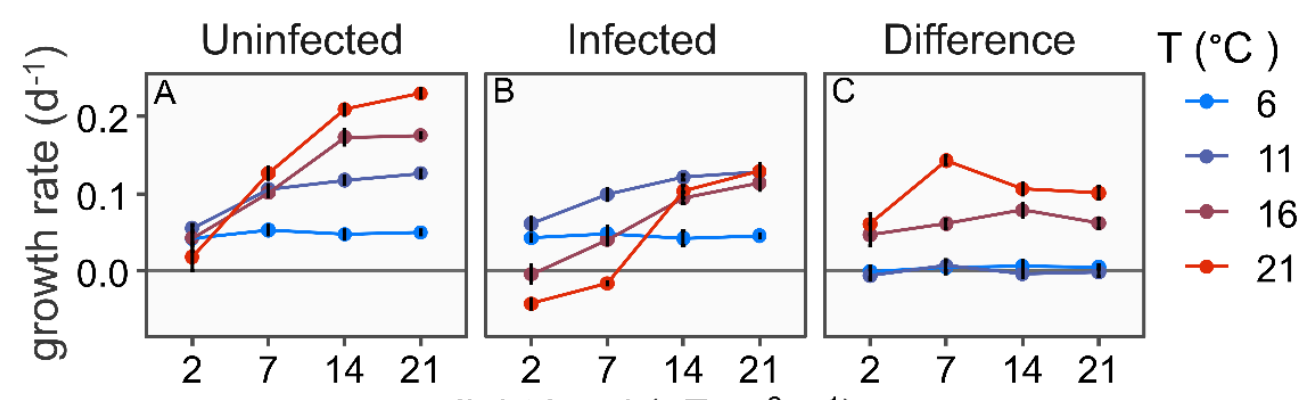

light level $\left(\mu \mathrm{E} \mathrm{m}^{-2} \mathrm{~s}^{-1}\right)$
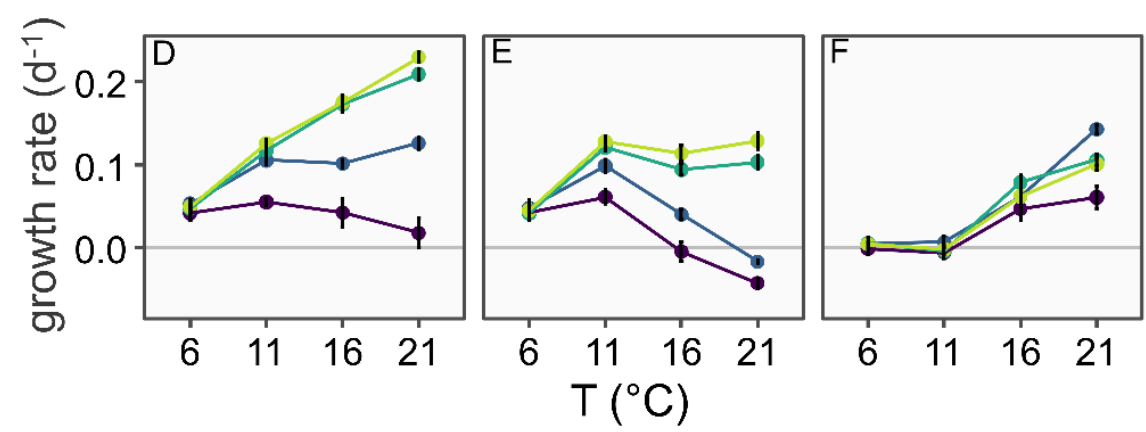

\section{Light}

$\left(\mu \mathrm{E} \mathrm{m} \mathrm{m}^{-2} \mathrm{~s}^{-1}\right)$

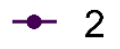

$\rightarrow 7$

$\rightarrow 14$

$-21$

Figure 1. Planktothrix growth rate varies strongly with temperature, light and infection status A: Growth rate of uninfected and infected P. rubescens as a function of light at each of the 4 temperatures tested. The effect of the interaction between light and temperature is clearly visible both in infected and uninfected treatments. Infection reduces growth rate at 16 and $21^{\circ} \mathrm{C}$ but not at 6 and $11{ }^{\circ} \mathrm{C}$. Within each temperature, changing light has little effect on the difference in growth rate between infected and uninfected treatments. B: The same data, viewed with temperature on $\mathrm{X}$-axis and with light levels indicated by color. Within each light level, changing temperature has a large effect on the difference in growth rate between infected and uninfected treatments. In all panels dots represent mean growth rates and error bars represent the standard error of the mean.

Effects of chytrid infection on Planktothrix growth

Chytrids did not affect the growth rate of $P$. rubescens at temperatures of $11{ }^{\circ} \mathrm{C}$ and lower. The growth rate remained unchanged between the infected and uninfected treatment, confirming the refuge for $P$. rubescens at low temperatures (Fig. $1 \mathrm{C}$ ). At temperatures of $16{ }^{\circ} \mathrm{C}$ and higher, 
the chytrid infection led to a substantially lower growth rate at all light levels tested. The reduction is similar across light levels (Fig. $1 \mathrm{C}$ ). The biggest effect of the chytrid infection occurs at the highest temperature, with a big change in growth rate. This results in negative growth rates of $P$. rubescens at lower light levels (Fig. $1 \mathrm{~B}, 1 \mathrm{E}$ ). Growth of $P$. rubescens is very low at high temperature and low light $\left(21^{\circ} \mathrm{C}, 2 \mu \mathrm{E} \mathrm{m}^{-2} \mathrm{~s}^{-1}\right)$; infection led to further deterioration, resulting in negative growth rates for $P$. rubescens in the infected treatment (21 ${ }^{\circ} \mathrm{C}$, at 2 and $7 \mu \mathrm{E} \mathrm{m}^{-2} \mathrm{~s}^{-1}$ and $16^{\circ} \mathrm{C}$ at $2 \mu \mathrm{E} \mathrm{m}^{-2} \mathrm{~s}^{-1}$ ).
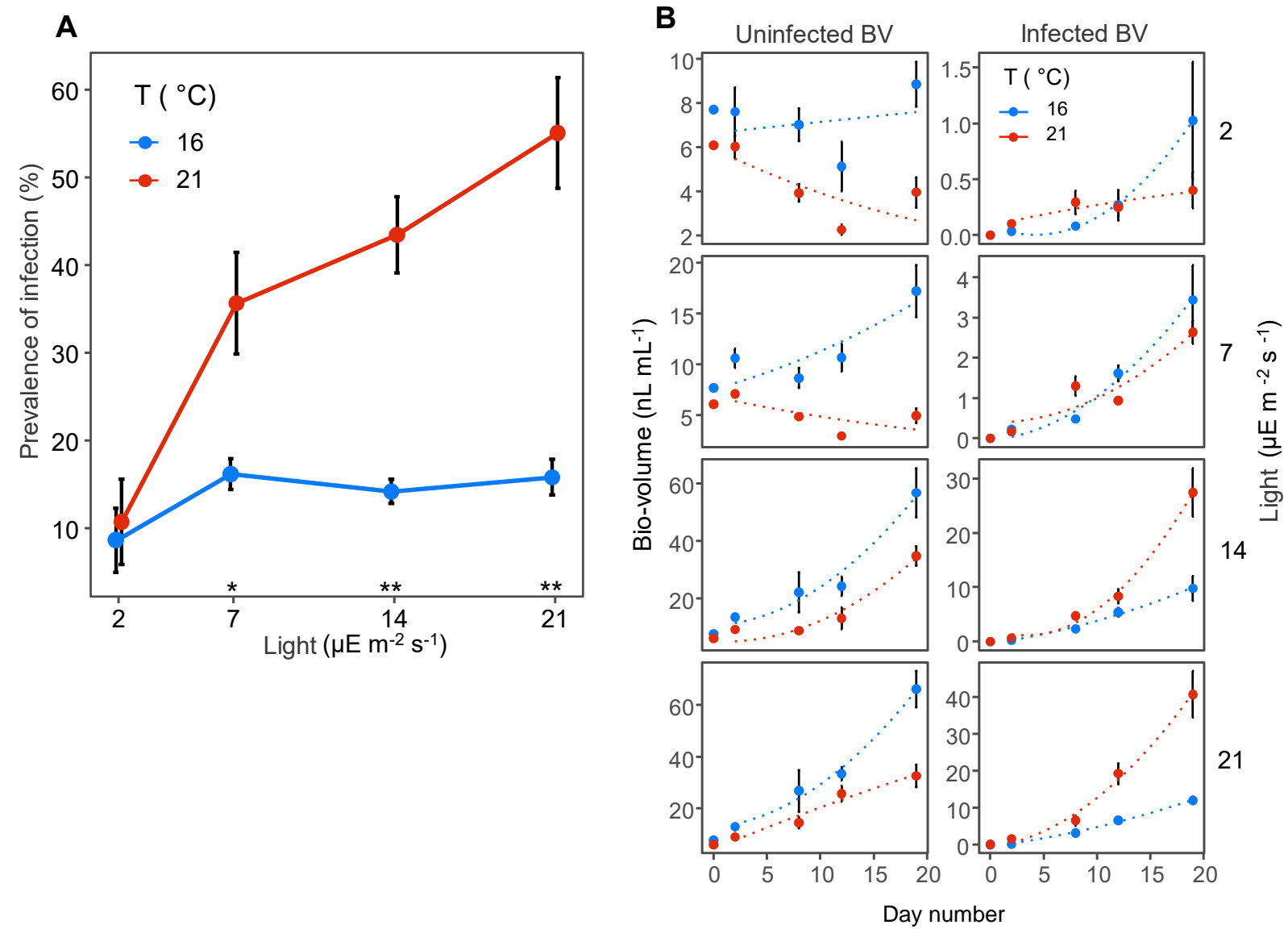

Figure 2. $P$. rubescens is affected more strongly by the chytrid parasite at $21^{\circ} \mathrm{C}$, especially at high light. (A) Prevalence of infection as a function of light level on the last day of the experiment. The prevalence of infection increases with increasing light at $21^{\circ} \mathrm{C}$, but not at 16 ${ }^{\circ} \mathrm{C}$. At 6 and $11^{\circ} \mathrm{C}$ no infected filaments were observed, and lines are not shown. (B) $P$. rubescens biovolume in the infected treatment, divided into uninfected and infected fractions; uninfected biovolume is shown in the left- and infected in the right-hand panels respectively. Asterisks indicate a statistically significant difference between means: ${ }^{*} p<0.05,{ }^{* *} p<0.01$

Temperature and light effects on chytrid growth and infection prevalence Temperature and light interact to shape chytrid growth, as indicated by the varying prevalence of infection on the last day of the experiment (Fig. 2A), and the development of the infected and uninfected fractions of the biovolume (Fig. $2 \mathrm{~B}$, note that we refer here to the infected and uninfected biovolume fractions from the infected treatment). Temperature is a major factor for chytrid growth showing increased prevalence of infection, especially at high 
light (Fig. 2A), and increased growth of infected BV with higher temperature (Fig. 2B). The $\left.\mathrm{m}^{-2} \mathrm{~s}^{-1}\right)$, the effect of temperature is absent, and the prevalence of infection is similar between $16^{\circ} \mathrm{C}$ and $21^{\circ} \mathrm{C}$. Chytrid growth, as indicated by the growing fraction of infected $P$. rubescens biovolume, was only higher at $21^{\circ} \mathrm{C}$ than at $16^{\circ} \mathrm{C}$ with light levels at or above $14 \mu \mathrm{E} \mathrm{m} \mathrm{m}^{-2} \mathrm{~s}^{-1}$. Furthermore, growth of uninfected biovolume at $16^{\circ} \mathrm{C}$ was higher than at $21{ }^{\circ} \mathrm{C}$ even though growth of $P$. rubescens in the uninfected treatment is higher at $21{ }^{\circ} \mathrm{C}$ than at $16^{\circ} \mathrm{C}$ (Fig. $3.2 \mathrm{~B}$ ). This indicates that at $21^{\circ} \mathrm{C} \mathrm{P}$. rubescens is more vulnerable to chytrid infection than at $16^{\circ} \mathrm{C}$, more so with increasing light levels as is also shown for P. rubescens growth (Fig 3.1). At $21{ }^{\circ} \mathrm{C}$ increased light also leads to a greater increase of the prevalence of infection compared to 16 ${ }^{\circ} \mathrm{C}$. We did not find a low light refuge for P. rubescens. On the contrary, our experimental results show a large reduction in the growth rate of $P$. rubescens at low light with chytrid infection, especially at high temperatures (Fig. 1).

\section{Dynamical model}

282 We investigated how temperature and light would interact to drive $P$. rubescens - chytrid dynamics using a host - parasite model. We see a clear refugium defined largely by conditions of low temperature (Fig. 3A), identified by the absence of zoospores (Fig. $3 \mathrm{~B}$ ) and the distinct outcomes of the model (the 'only host' region in Fig. $3 \mathrm{C}$ ). The low temperature refuge is explained by the absence of chytrid infections at low temperature. This refuge is also dependent on light level; between approximately 13 and $15 \mathrm{C}$, a refuge exists at very low light levels and at high (for this experiment) light levels, while intermediate light levels allow for persistence of the parasite. The highest densities of $P$. rubescens are found in refuge conditions and decrease with increasing temperature and light (Fig. $3 \mathrm{~A}$ ). The chytrid abundance is at its

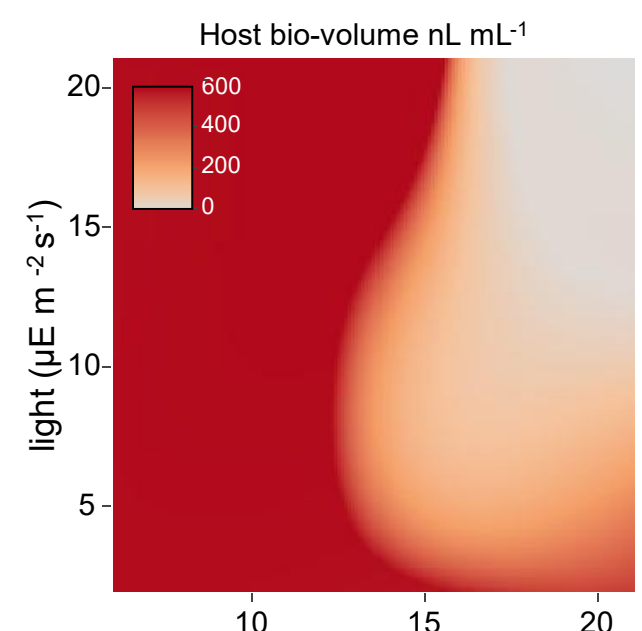

10

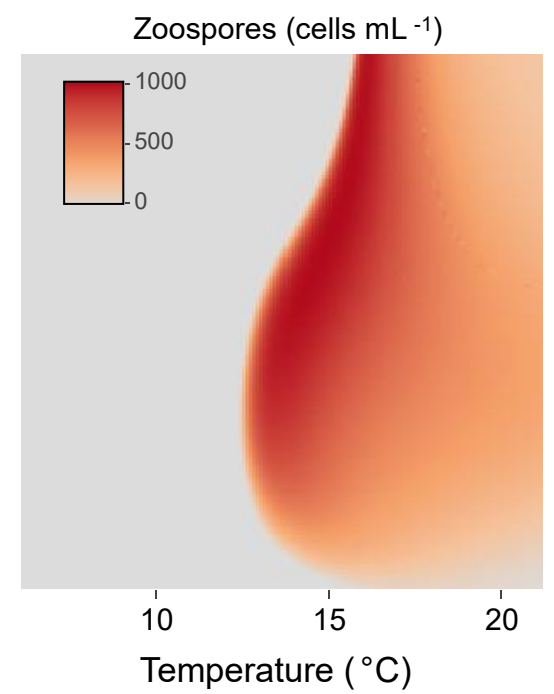

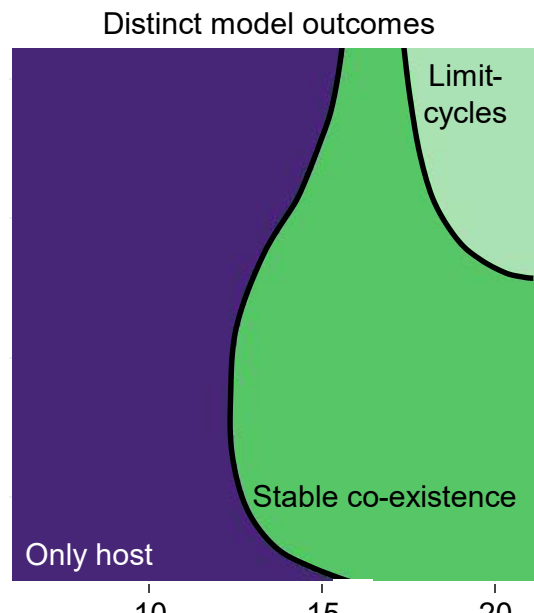

10
15
20

Figure 3. Outcomes of modelled host-parasite dynamics after 400 model days. (A) Host biovolume is greatest at temperatures below $13^{\circ} \mathrm{C}$ and decreases above it. Moreover, at high temperatures, P. rubescens biovolume decreases with increasing in light. (B) Chytrid zoospore abundance is highest at intermediate temperature at light levels between 10 and 22 $\mu \mathrm{E} \mathrm{m} \mathrm{m}^{-2} \mathrm{~s}^{-1}$ it drops when temperatures increase above $17^{\circ} \mathrm{C}$. (C) Green parameter region indicates a stable coexistence of host and parasite, light-green indicates limit cycles of host and parasite density, and purple indicates that the host survives but the parasite goes extinct. Note that abundances shown in the limit cycle region are averages over the course of one cycle. 
highest at an intermediate temperature between 14 and $16{ }^{\circ} \mathrm{C}$, and light levels above $10 \mu \mathrm{E} \mathrm{m} \mathrm{m}^{-2}$ $\mathrm{s}^{-1}$.

Several distinct outcomes are observed at the different combinations of temperature and light we explored (Fig. $3 \mathrm{C}$, Fig. 4$)$. At low temperatures $\left(<13^{\circ} \mathrm{C}\right)$, only the uninfected host can survive irrespective of light levels (Fig. 3 A). Further, at extremely low light levels, only the uninfected host survives irrespective of the temperature. (Figs. 3A,C) The host (uninfected and infected) and the chytrid coexist at intermediate to high temperatures (Fig. ${ }_{3} \mathrm{C}$ ). However, the temperature range for coexistence is drastically reduced at high light levels (Fig. ${ }_{3} \mathrm{C}$ ). Finally, at high temperature and light levels, we find a limit cycle involving the uninfected host, infected host and the chytrid. Therefore, high temperatures and light levels together destabilize the coexistence of the host and the chytrid (Fig. 4).

Temperature $\left({ }^{\circ} \mathrm{C}\right)$

$6^{\circ} \mathrm{C}$
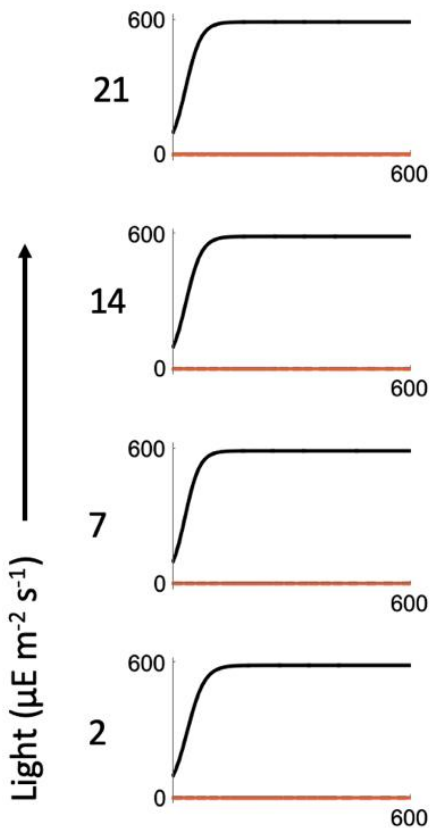

- Uninfected host $11^{\circ} \mathrm{C}$
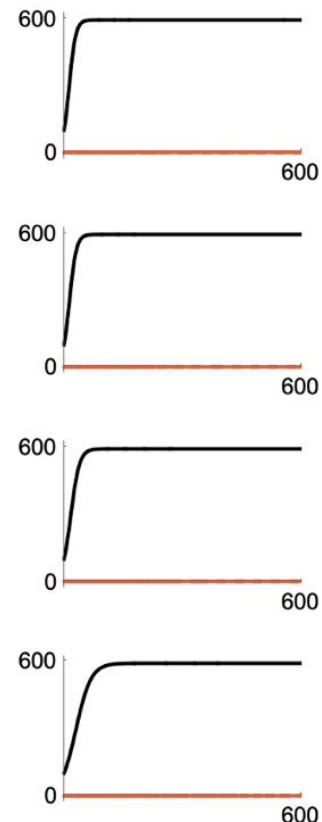

$16^{\circ} \mathrm{C}$
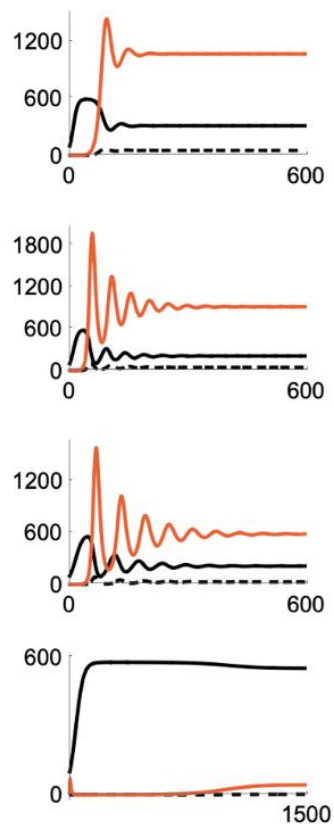

$21^{\circ} \mathrm{C}$
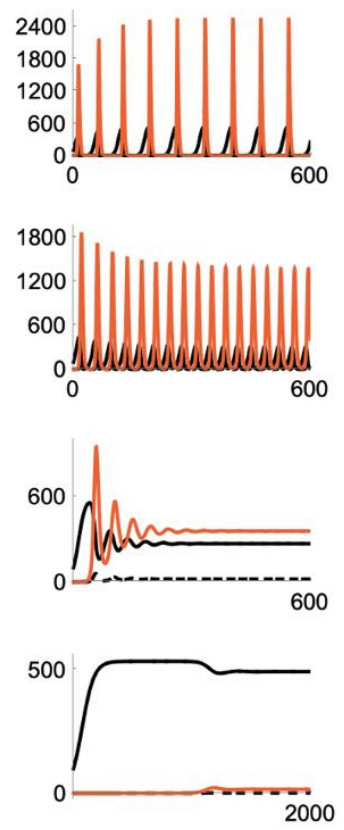

Chytrid

Figure 4. Model output of $P$. rubescens - chytrid dynamics as they reach a long-term attractor (equilibrium or a limit cycle). The solid and dashed black lines indicate uninfected and infected host densities respectively, while the red line indicates the chytrid density. At low temperatures, $P$. rubescens has a thermal refuge and grows to the carrying capacity. With increasing light and temperature there is a shift from stable coexistence $\left(16^{\circ} \mathrm{C}\right.$ with 7 , $14,21 \mu \mathrm{E} \mathrm{m} \mathrm{m}^{-2} \mathrm{~s}^{-1}$, and $21^{\circ} \mathrm{C}$ with $\left.7 \mu \mathrm{E} \mathrm{m} \mathrm{m}^{-2} \mathrm{~s}^{-1}\right)$ to limit cycles $\left(21^{\circ} \mathrm{C}\right.$ with $\left.14,21 \mu \mathrm{E} \mathrm{m} \mathrm{m}^{-2} \mathrm{~s}^{-1}\right)$.

\section{Discussion}

P. rubescens - chytrid growth and infection dynamics

We show that dynamics of $P$. rubescens and their chytrid parasites are heavily shaped by the interaction of temperature and light (Figs. 1-33). It has been previously shown that temperature and light are important factors (Frenken et al., 2016; Rohrlack et al., 2015; Scholz et 
al., 2017; Tao et al., 2020), but the effect of the interaction between temperature and light has not been well studied. To our knowledge, the only work on the interaction of temperature and light on chytrid-host dynamics is by (Bruning, 1991a), showing a complex interaction with temperature and light affecting chytrid infection dynamics with Asterionella as host. $P$. rubescens growth is most affected by chytrid infections at higher light and temperature levels. Even though we find relatively low infectivity of chytrids under low light, intrinsic slow growth due to low light means that chytrids can arrest $P$. rubescens growth. We thus do not find a physiological refuge for $P$. rubescens at low light as we hypothesized and was found for the diatom Asterionella (Bruning, 1991a).

\section{Indirect light resource utilization by chytrids}

The chytrids in this experiment are obligate parasites (Sønstebø \& Rohrlack, 2011), feeding on the host as a resource, and thus light is not a direct resource for the chytrids. Increased light does increase the release of dissolved organic carbon (DOC) by phytoplankton, affecting the affinity of zoospores to their host through chemotaxis and thus the interaction between the host and the parasite. (Bruning, 1991b, 1991a; Muehlstein et al., 1988; Van den Wyngaert et al., 2013). However, here we find that at the lowest light level, increased temperature does not lead to increased prevalence of infection, and that increased light leads to a very small increase in the prevalence of infection at $16^{\circ} \mathrm{C}$. At $16^{\circ} \mathrm{C}$, temperature may be the limiting factor for chytrid growth, and more light does not lead to increased chytrid growth. At $21^{\circ} \mathrm{C}$ however, the chytrid growth increases with light and thus might be resource limited, with increased photosynthetic resources available at higher light intensity indicating indirect light utilization by acquiring energy resources from photosynthesis of the host while it is infected. Optimizing resource utilization by feeding while the host is actively photosynthesizing makes sense from an evolutionary perspective and is further suggested by the absence of a temperature effect at the lowest light level. This would not be expected if the chytrid uses only existing host resources at the time of infection for its reproduction and growth. Instead it may feed off the host while alive, as occurs in most parasites (Esch \& Fernández, 1993). A recent study by (Tao et al., 2020) has shown that increased light intensity and quality leads to bigger sporangia and increased chytrid transmission, furthermore indicating that chytrids indirectly utilize light through host photosynthesis. Another explanation could be that hosts grown under higher light stores more carbohydrates, and as such are a better energy source for the chytrid parasite.

\section{Dynamic model outcome and implications}

The model shows three distinct outcomes over the range of conditions we explored: 1 ) only the host survives. 2) stable coexistence between the parasite and the host. 3) limit cycles of host and parasite. (Fig. ${ }_{3} \mathrm{C}$, Fig 4). Limit cycles occur at high temperatures and high light intensities (Fig. 3C, Fig. 4). Under these conditions, P. rubescens can grow rapidly but is vulnerable to infection, and infection under these conditions leads to a rapid decline of the host to very low densities. In a natural setting, chytrids are found both at low densities with only minimal impact on the host (Gerphagnon et al., 2017; Maier \& Peterson, 2017; Sime-Ngando, 2012), as well as at high densities and high infection incidence that can rapidly terminate host blooms (Frenken et al., 2016; Ibelings et al., 2011; Kagami \& Urabe, 2002; van Donk \& Ringelberg, 1983). In natural conditions, it is possible that periods of very low density could lead to local extinction 
of both host and parasite and so may not be congenial to the persistence of this host-parasite system despite the model outcome of limit cycles.

This suggests an interesting biotic alternative to abiotic factors explaining the niche of $P$. rubescens. $P$. rubescens is almost solely found around the $0.1-1 \%$ light level in stratified lakes (Walsby, 2005). The prevailing hypothesis is that they have adapted to a specific niche in the lake with relatively high nutrient levels, lower temperatures, and low light, where they outcompete other phytoplankton because they possess the accessory pigments phycoerythrin and phycocyanin (Oberhaus et al., 2007). However, experimental data also shows that growth rates of $P$. rubescens increase when temperature and light are increased beyond the limiting conditions found at the bottom of the euphotic zone; light levels up to $200 \mu \mathrm{E} \mathrm{m}^{-2} \mathrm{~s}^{-1}$, and temperatures up $25{ }^{\circ} \mathrm{C}$ still promote growth (Bright \& Walsby, 2000; Davis \& Walsby, 2002; Oberhaus et al., 2007). But at these high temperature and light levels, $P$. rubescens would be very sensitive to chytrid infections, and not able to sustain high biovolume concentrations, especially in competition with other phytoplankton species. Chytrid infection might thus prove to be an important cause of the vertical distribution of $P$. rubescens in stratified lakes. The model furthermore shows that the thermal refuge extends to higher temperatures at higher light levels, although we do not have experimental data to confirm this.

\section{Conclusions}

We have shown that the host - parasite interaction of $P$. rubescens and chytrids is strongly affected by the interaction of temperature and light. Our results confirm the existence of a thermal refugium below at least $11{ }^{\circ} \mathrm{C}$, and that this may vary with light intensity although there appears to be no specific low light refuge. In general, vulnerability of $P$. rubescens to chytrid infections increases with temperature and light. This may explain why $P$. rubescens is hardly ever found under warmer or high-light conditions, even though lab experiments show that these conditions lead to higher growth rates in the absence of chytrids. Although the effect of light on chytrid infection is mostly examined from the perspective of chemotaxis, the indirect effects of light through improved resource availability may be more important . Our results highlight how abiotic and biotic environmental factors can interact in complex ways to affect ecological dynamics.

\section{Acknowledgements}

The authors gratefully acknowledge Thomas Rohrlack for early discussions which greatly helped putting us in the research direction described here.

\section{Data availability statement}

The datasets generated during and/or analysed during the current study will be made available in the Zenodo repository on acceptance of this manuscript.

\section{References}

Agha, R., Saebelfeld, M., Manthey, C., Rohrlack, T., \& Wolinska, J. (2016). Chytrid parasitism facilitates trophic transfer between bloom-forming cyanobacteria and zooplankton (Daphnia). Scientific Reports, 6. https://doi.org/10.1038/srep35039 
Almocera, A. E. S., Hsu, S. B., \& Sy, P. W. (2019). Extinction and uniform persistence in a microbial food web with mycoloop: Limiting behavior of a population model with parasitic fungi. Mathematical Biosciences and Engineering, 16(1), 516-537. https://doi.org/10.3934/mbe.2019024

Bosch, J., Martõânez-solano, Ä., Garcõâa-parõâs, M., Martínez-Solano, I., García-París, M., Martõânez-solano, Ä., \& Garcõâa-parõâs, M. (2001). Evidence of a chytrid fungus infection involved in the decline of the common midwife toad (Alytes obstetricans) in protected areas of central Spain. Biological Conservation, 97(3), 331-337. https://doi.org/10.1016/S00063207(00)00132-4

Bright, D. I., \& Walsby, A. (2000). The daily integral of growth by Planktothrix rubescens calculated from growth rate in culture and irradiance in Lake Zürich. New Phytologist, 146(2), 301-316. https://doi.org/10.1046/j.1469-8137.2000.00640.x

Bruning, K. (1991a). Effects of temperature and light on the population dynamics of the AsterionellaRhizophydium association. Journal of Plankton Research, 13(4), 707-719. https://doi.org/10.1093/plankt/13.4.707

Bruning, K. (1991b). Infection of the diatom Asterionella by a chytrid. I. Effects of light on reproduction and infectivity of the parasite. Journal of Plankton Research, 13(1), 103-117. https://doi.org/10.1093/plankt/13.1.103

Bruning, K. (1991c). Infection of the diatom Asterionella by a chytrid. II. Effects of light on survival and epidemic development of the parasite. Journal of Plankton Research, 13(1), 119-129. https://doi.org/10.1093/plankt/13.1.119

Bruning, K., Lingeman, R., \& Ringelberg, J. (1992). Estimating the impact of fungal parasites on phytoplankton populations. Limnology and Oceanography, 37(2), 252-260. https://doi.org/10.4319/lo.1992.37.2.0252

Brussaard, C. P. D., Kuipers, B., \& Veldhuis, M. J. W. (2005). A mesocosm study of Phaeocystis globosa population dynamics: I. Regulatory role of viruses in bloom control. Harmful Algae, 4(5), 859-874. https://doi.org/10.1016/j.hal.2004.12.015

Champely, S. (2018). PairedData (1.1.1).

Conroy, J. D., Kane, D. D., Quinlan, E. L., Edwards, W. J., \& Culver, D. A. (2017). Abiotic and biotic controls of phytoplankton biomass dynamics in a freshwater tributary, estuary, and large lake ecosystem: Sandusky bay (lake erie) chemostat. Inland Waters, 7(4), 473-492. https://doi.org/10.1080/20442041.2017.1395142

Davis, P. A., \& Walsby, A. (2002). Comparison of measured growth rates with those calculated from rates of photosynthesis in Planktothrix spp. isolated from Blelham Tarn, English Lake District. New Phytologist, 156(2), 225-239. https://doi.org/10.1046/j.1469-8137.2002.00495.x

Díez, B., \& Ininbergs, K. (2013). Ecological importance of cyanobacteria. In Cyanobacteria (pp. 4163). John Wiley \& Sons, Ltd. https://doi.org/10.1002/9781118402238.ch3 
Edwards, K. F., Thomas, M. K., Klausmeier, C. A., \& Litchman, E. (2016). Phytoplankton growth and the interaction of light and temperature : A synthesis at the species and community level. 12321244. https://doi.org/10.1002/Ino.10282

Esch, G. W., \& Fernández, J. C. (1993). Introduction. In A Functional Biology of Parasitism (pp. 1-25). Springer Netherlands. https://doi.org/10.1007/978-94-011-2352-5_1

Fallowfield, H. J., \& Daft, M. J. (1988). The extracellular release of dissolved organic carbon by freshwater cyanobacteria and algae and the interaction with Lysobacter CP-1. Br Phycol J, 1617(23), 317-326. https://doi.org/10.1080/00071618800650351

Frenken, T., Alacid, E., Berger, S. A., Bourne, E. C., Gerphagnon, M., Grossart, H. P., Gsell, A. S., Ibelings, B. W., Kagami, M., Küpper, F. C., Letcher, P. M., Loyau, A., Miki, T., Nejstgaard, J. C., Rasconi, S., Reñé, A., Rohrlack, T., Rojas-Jimenez, K., Schmeller, D. S., ... Rica, C. (2017). Integrating chytrid fungal parasites into plankton ecology: research gaps and needs. Environmental Microbiology, 19(10), 3802-3822. https://doi.org/10.1111/1462-2920.13827

Frenken, T., Miki, T., Kagami, M., Van de Waal, D. B., Van Donk, E., Rohrlack, T., \& Gsell, A. S. (2020). The potential of zooplankton in constraining chytrid epidemics in phytoplankton hosts. Ecology, 101(1). https://doi.org/10.1002/ecy.2900

Frenken, T., Velthuis, M., de Senerpont Domis, L. N., Stephan, S., Aben, R., Kosten, S., van Donk, E., \& Van de Waal, D. B. (2016). Warming accelerates termination of a phytoplankton spring bloom by fungal parasites. Global Change Biology, 22(1), 299-309. https://doi.org/10.1111/gcb.13095

Frenken, T., Wierenga, J., van Donk, E., Declerck, S. A. J., de Senerpont Domis, L. N., Rohrlack, T., \& Van de Waal, D. B. (2018). Fungal parasites of a toxic inedible cyanobacterium provide food to zooplankton. Limnology and Oceanography, 63(6), 2384-2393. https://doi.org/10.1002/Ino.10945

Fristachi, A., Sinclair, J. L., Hall, S., Berkman, J. A. H., Boyer, G., Burkholder, J., Burns, J., Carmichael, W., Dufour, A., Frazier, W., Morton, S. L., O’Brien, E., \& Walker, S. (2008). Occurrence of cyanobacterial harmful algal blooms workgroup report. Advances in Experimental Medicine and Biology, 619(January), 45-103. https://doi.org/10.1007/978-0-387-75865-7_3

Gerla, D. J., Gsell, A. S., Kooi, B. W., Ibelings, B. W., Van Donk, E., \& Mooij, W. M. (2013). Alternative states and population crashes in a resource-susceptible-infected model for planktonic parasites and hosts. FMeier, M. H. et al. (2015) 'Neuropsychological Decline in Schizophrenia from the Premorbid to Post-Onset Period: Evidence from a Population-Representative Longitudinal Study', American Journal of Psychiatry, 171(1), Pp. 91-101. Doi: 10.1176/Appi.Ajp.2013, 58(3), 538-551. https://doi.org/10.1111/fwb.12010

Gerphagnon, M., Colombet, J., Latour, D., \& Sime-Ngando, T. (2017). Spatial and temporal changes of parasitic chytrids of cyanobacteria. Scientific Reports, 7(1), 6056. https://doi.org/10.1038/s41598-017-06273-1

Gerphagnon, M., Macarthur, D. J., Gachon, C., Ogtrop, F. Van, Latour, D., Lilje, O., Gleason, F. H., \& Sime-ngando, T. (2009). The biological factors affecting the dynamics of cyanobacterial blooms. 2008. 
Gleason, F. H., Jephcott, T. G., Upper, F. C. K., Karpov, S. A., Guillou, L., Ogtrop, F. F. V. A. N., Pascal, B., Küpper, F. C., Gerphagnon, M., Sime-Ngando, T., Karpov, S. A., Guillou, L., \& van Ogtrop, F. F. (2015). Potential roles for recently discovered chytrid parasites in the dynamics of harmful algal blooms. Fungal Biology Reviews, 29(1), 20-33. https://doi.org/10.1016/j.fbr.2015.03.002

Guillard, R. R. L., \& J.Lorenzen, C. (1972). Yellow-green algae with chlorophyllid C. In Phycology (Vol. 8, pp. 10-14).

Han, B. P., Virtanen, M., Koponen, J., \& Straškraba, M. (2000). Effect of photoinhibition on algal photosynthesis: A dynamic model. Journal of Plankton Research, 22(5), 865-885. https://doi.org/10.1093/plankt/22.5.865

Hatcher, M. J., \& Dunn, A. M. (2011). Parasites in ecological communities: from interactions to ecosystems. Cambridge University Press.

Huisman, J., Codd, G. A., Paerl, H. W., Ibelings, B. W., Verspagen, J. M. H., \& Visser, P. M. (2018). Cyanobacterial blooms. Nature Reviews Microbiology 2018 16:8, 16(8), 471-483. https://doi.org/10.1038/s41579-018-0040-1

Ibelings, B. W. (1996). Changes in photosynthesis in response to combined irradiance and temperature stress in cyanobacterial surface waterblooms. Journal of Phycology, 32(4), 549557. https://doi.org/10.1111/j.0022-3646.1996.00549.x

Ibelings, B. W., Gsell, A. S., Mooij, W. M., Van Donk, E., Van Den Wyngaert, S., \& De Senerpont Domis, L. N. (2011). Chytrid infections and diatom spring blooms: Paradoxical effects of climate warming on fungal epidemics in lakes. Freshwater Biology, 56(4), 754-766. https://doi.org/10.1111/j.1365-2427.2010.02565.x

Kagami, M., De Bruin, A., Ibelings, B. W., \& Van Donk, E. (2007). Parasitic chytrids: Their effects on phytoplankton communities and food-web dynamics. Hydrobiologia, 578(1), 113-129. https://doi.org/10.1007/s10750-006-0438-z

Kagami, M., \& Urabe, J. (2002). Mortality of the planktonic desmid, Staurastrum dorsidentiferum , due to interplay of fungal parasitism and low light conditions. SIL Proceedings, 1922-2010, 28(2), 1001-1005. https://doi.org/10.1080/03680770.2001.11901868

Kagami, M., von Elert, E., Ibelings, B. W., de Bruin, A., \& van Donk, E. (2007). The parasitic chytrid, Zygorhizidium, facilitates the growth of the cladoceran zooplankter, Daphnia, in cultures of the inedible alga, Asterionella. Proceedings. Biological Sciences / The Royal Society, 274(April), 1561-1566. https://doi.org/10.1098/rspb.2007.0425

Kurmayer, R., Deng, L., \& Entfellner, E. (2016). Role of toxic and bioactive secondary metabolites in colonization and bloom formation by filamentous cyanobacteria Planktothrix. Harmful Algae, 54, 69-86. https://doi.org/10.1016/j.hal.2016.01.004

Legnani, E., Copetti, D., Oggioni, A., Tartari, G., Palumbo, M. T., \& Morabito, G. (2005). Planktothrix rubescens ' seasonal dynamics and vertical distribution in. Journal of Limnology, 64(1), 61-73.

Lips, K. R., Brem, F., Brenes, R., Reeve, J. D., Alford, R. A., Voyles, J., Carey, C., Livo, L., Pessier, A. P., \& Collins, J. P. (2005). Emerging infectious disease and the loss of biodiversity in a Neotropical amphibian community. 
Maier, M. A., \& Peterson, T. D. (2017). Prevalence of chytrid parasitism among diatom populations in the lower Columbia River (2009-2013). Freshwater Biology, 62(2), 414-428. https://doi.org/10.1111/fwb.12876

Marcogliese, D. J. (2004). Parasites: Small Players with Crucial Roles in the Ecological Theater. EcoHealth, 1(2), 151-164. https://doi.org/10.1007/s10393-004-0028-3

McKenzie, V. J., \& Peterson, A. C. (2012). Pathogen pollution and the emergence of a deadly amphibian pathogen. Molecular Ecology, 21(21), 5151-5154. https://doi.org/10.1111/mec.12013

Miki, T., Takimoto, G., \& Kagami, M. (2011). Roles of parasitic fungi in aquatic food webs: A theoretical approach. Freshwater Biology, 56(6), 1173-1183. https://doi.org/10.1111/j.13652427.2010.02562.x

Muehlstein, L. K., Amon, J. P., \& Leffler, D. L. (1988). Chemotaxis in the Marine Fungus Rhizophydium littoreum. Applied and Environmental Microbiology, 54(7), 1668-1672. https://doi.org/10.1128/aem.54.7.1668-1672.1988

Mueller, B., den Haan, J., Visser, P. M., Vermeij, M. J. A., \& van Duyl, F. C. (2016). Effect of light and nutrient availability on the release of dissolved organic carbon (DOC) by Caribbean turf algae. Scientific Reports 2016 6:1, 6(1), 1-9. https://doi.org/10.1038/srep23248

Oberhaus, L., Briand, J. F., Leboulanger, C., Jacquet, S., \& Humbert, J. F. (2007). Comparative effects of the quality and quantity of light and temperature on the growth of Planktothrix agardhii and P. rubescens 1. Journal of Phycology, 43(6), 1191-1199. https://doi.org/10.1111/j.15298817.2007.00414.x

Paterson, R. A. (1960). Infestation of Chytridiaceous Fungi on Phytoplankton in Relation to Certain Environmental Factors. Ecology, 41(3), 416-424. https://doi.org/10.2307/1933316

Plaas, H. E., \& Paerl, H. W. (2021). Toxic Cyanobacteria: A Growing Threat to Water and Air Quality. In Environmental Science and Technology (Vol. 55, Issue 1, pp. 44-64). American Chemical Society. https://doi.org/10.1021/acs.est.0c06653

R Core Team. (2021). R: A Language and Environment for Statistical Computing.

Reynolds, C. S. (2009). Growth and replication of phytoplankton. In The Ecology of Phytoplankton (pp. 145-177). Cambridge University Press. https://doi.org/10.1017/CBO9780511542145.005

Rohrlack, T., Christiansen, G., \& Kurmayer, R. (2013). Putative antiparasite defensive system involving ribosomal and nonribosomal oligopeptides in cyanobacteria of the genus planktothrix. Applied and Environmental Microbiology, 79(8), 2642-2647. https://doi.org/10.1128/AEM.03499-12

Rohrlack, T., Haande, S., Molversmyr, Å., \& Kyle, M. (2015). Environmental Conditions Determine the Course and Outcome of Phytoplankton Chytridiomycosis. 1-17. https://doi.org/10.1371/journal.pone.0145559

RStudio Team. (2021). RStudio: Integrated Development Environment for R (1.4.1106). PBC. 
Scholz, B., Vyverman, W., Küpper, F. C., Ólafsson, H. G., \& Karsten, U. (2017). Effects of environmental parameters on chytrid infection prevalence of four marine diatoms: $A$ laboratory case study. Botanica Marina, 60(4), 419-431. https://doi.org/10.1515/bot-20160105

Șen, B. (1988). Fungal parasitism of planktonic algae in Shearwater. IV: Parasitic occurrence of a new chytrid species on the blue-green alga Microcystis aeruginosa Kuetz. emend. Elenkin. Undefined.

Sime-Ngando, T. (2012). Phytoplankton chytridiomycosis: Fungal parasites of phytoplankton and their imprints on the food web dynamics. In Frontiers in Microbiology (Vol. 3, Issue OCT, p. 361). Frontiers Research Foundation. https://doi.org/10.3389/fmicb.2012.00361

Sime-Ngando, T., Lafferty, K. D., \& Biron, D. G. (2007). Roles and Mechanisms of Parasitism in Aquatic Microbial Communities. https://doi.org/10.3389/978-2-88919-588-6

Skerratt, L. F., Berger, L., Speare, R., Cashins, S., Mcdonald, K. R., Phillott, A. D., Hines, H. B., \& Kenyon, N. (2007). Spread of chytridiomycosis has caused the rapid global decline and extinction of frogs. EcoHealth, 4(2), 125-134. https://doi.org/10.1007/s10393-007-0093-5

Soetaert, K., Petzoldt, T., \& Setzer, R. W. (2010). Solving Differential Equations in $\{$ R\}: Package deSolve. Journal of Statistical Software, 33(9), 1-25. https://doi.org/10.18637/jss.v033.i09

Sommer, U., Adrian, R., De Senerpont Domis, L., Elser, J. J., Gaedke, U., Ibelings, B., Jeppesen, E., Carlos Molinero, J., Mooij, W. M., van Donk, E., Winder, M., Lürling, M., Molinero, J. C., Mooij, W. M., van Donk, E., Winder, M., Carlos Molinero, J., Mooij, W. M., van Donk, E., \& Winder, M. (2012). Beyond the plankton ecology group (PEG) model: Mechanisms driving plankton succession. Annual Review of Ecology, Evolution, and Systematics, 43(December), 429-448. https://doi.org/10.1146/annurev-ecolsys-110411-160251

Sommer, U., Maciej Gliwics, Z., Lampert, W., \& Duncan, A. (1986). The PEG-model of seasonal succession of planktonic events in fresh waters. Archiv Für Hydrobiologie, 106(4), 433-471.

Sønstebø, J. H., \& Rohrlack, T. (2011). Possible implications of Chytrid parasitism for population subdivision in freshwater cyanobacteria of the genus Planktothrix. Applied and Environmental Microbiology, 77(4), 1344-1351. https://doi.org/10.1128/AEM.02153-10

Tao, Y., Wolinska, J., Hölker, F., \& Agha, R. (2020). Light intensity and spectral distribution affect chytrid infection of cyanobacteria via modulation of host fitness. Parasitology, 147(11), 12061215. https://doi.org/10.1017/S0031182020000931

Van den Wyngaert, S., Gsell, A. S., Spaak, P., \& Ibelings, B. W. (2013). Herbicides in the environment alter infection dynamics in a microbial host-parasite system. Environmental Microbiology, 15(3), 837-847. https://doi.org/10.1111/j.1462-2920.2012.02874.x

van Donk, E., \& Ringelberg, J. (1983). The effect of fungal parasitism on the succession of diatoms in Lake Maarsseveen I (The Netherlands). Freshwater Biology, 13(3), 241-251. https://doi.org/10.1111/j.1365-2427.1983.tb00674.x 
bioRxiv preprint doi: https://doi org/10.1101/2022.02.24 481659; this version posted February $24,2022$. The copyright holder for this preprint (which was not certified by peer review) is the author/funder, who has granted bioRxiv a license to display the preprint in perpetuity. It is made available under aCC-BY 4.0 International license.

581

582

583

584

585

586

587

588

589

590

591

592

593

Walsby, A. (2005). Stratification by cyanobacteria in lakes: A dynamic buoyancy model indicates size limitations met by Planktothrix rubescens filaments. New Phytologist, 168(2), 365-376. https://doi.org/10.1111/j.1469-8137.2005.01508.x

Walsby, A., Ng, G., Dunn, C., \& Davis, P. A. (2004). Comparison of the depth where Planktothrix rubescens stratifies and the depth where the daily insolation supports its neutral buoyancy. New Phytologist, 162(1), 133-145. https://doi.org/10.1111/j.1469-8137.2004.01020.x

Wickham, H. (2016). ggplot2: Elegant Graphics for Data Analysis. Springer-Verlag New York.

Wickham, H., Averick, M., Bryan, J., Chang, W., McGowan, L. D., François, R., Grolemund, G., Hayes, A., Henry, L., Hester, J., Kuhn, M., Pedersen, T. L., Miller, E., Bache, S. M., Müller, K., Ooms, J., Robinson, D., Seidel, D. P., Spinu, V., ... Yutani, H. (2019). Welcome to the \{tidyverse\}. Journal of Open Source Software, 4(43), 1686. https://doi.org/10.21105/joss.01686 